\title{
Winter Wheat and Spring Barley Canopies under Strip-Till One-Pass Technology
}

\author{
Iwona Jaskulska * and Dariusz Jaskulski
}

Citation: Jaskulska, I.; Jaskulski, D. Winter Wheat and Spring Barley Canopies under Strip-Till One-Pass Technology. Agronomy 2021, 11, 426. https://doi.org/10.3390/ agronomy11030426

Academic Editor: Giuseppe De Mastro

Received: 30 January 2021

Accepted: 24 February 2021

Published: 26 February 2021

Publisher's Note: MDPI stays neutral with regard to jurisdictional claims in published maps and institutional affiliations.

Copyright: (c) 2021 by the authors. Licensee MDPI, Basel, Switzerland. This article is an open access article distributed under the terms and conditions of the Creative Commons Attribution (CC BY) license (https:/ / creativecommons.org/licenses/by/ $4.0 /)$.
Department of Agronomy, Faculty of Agriculture and Biotechnology, UTP University of Science and Technology, 7 prof. S. Kaliskiego St., 85796 Bydgoszcz, Poland; darekjas@utp.edu.pl

* Correspondence: jaskulska@utp.edu.pl

\begin{abstract}
Modern agriculture promotes non-inversion, ploughless tillage systems, and simplified plant cultivation methods. Environmentally friendly plant production technologies must nevertheless guarantee high yields of good quality. In the years 2017/18-2019/20, studies were carried out in which it was assumed that these conditions could be met by strip soil tillage with simultaneous application of fertilisers and paired-row sowing (strip-till one-pass (ST-OP). Two field experiments were conducted to compare two cereal cultivation technologies: ploughless, non-inversion tillage, seedbed preparation, entire-surface fertilisation, and narrowly spaced row sowing (PL-ES); and ST-OP, with two narrow spaced rows (12 cm apart) in a strip of tilled (paired-row sowing), fertilised soil, and a 24.4-cm-wide inter-row of untilled soil. Fields of winter wheat and spring barley were investigated, assessing plant density and spatial variation, plant height, yield components, and yield. The morphological and physiological indices of the plants and canopies determined were leaf area index (LAI), photosynthetically active radiation (PAR), leaf stomatal conductance, and relative chlorophyll content in leaves. The ST-OP technology provides uniform planting in the canopy, especially under conditions of insufficient rainfall. Fields of winter wheat and spring barley cultivated by this method featured shorter plants with more stalks with spikes, and spikes with greater weight and number of grains, than in the fields of cereals grown under PL-ES. The LAI and PAR indices in the narrow inter-rows were similar to the PL-ES technology and higher than in the wide, untilled inter-rows. Leaves of cereals grown under ST-OP contained more chlorophyll and had a higher leaf stomatal conductance. This technology, which provides higher winter wheat and spring barley yields, is an alternative to ploughless tillage with row sowing.
\end{abstract}

Keywords: cereals; ploughless tillage; strip tillage; paired-row sowing cereals; leaf area index (LAI); photosynthetically active radiation (PAR); stomatal conductance; chlorophyll content

\section{Introduction}

Non-inversion, ploughless tillage methods and systems are increasingly being used in modern sustainable and conservation agriculture. The soil is loosened and mixed with plant residues across the entire cultivated area or only in narrow strips [1-3]. Deep ploughless tillage creates relatively homogeneous soil conditions in the cultivated layer across an entire area $[4,5]$. Fields in this state can be sown using various methods. Depending on plant biology and cultivation method, it is possible to sow in rows of various widths in regular and irregular spacing [6,7]. Strip tillage is a non-inversion, reduced tillage method [8]. In strip-tillage, strips of deeply loosened soil of several centimetres to several tens of centimetres wide are prepared for sowing seeds. These strips are separated by strips of untilled soil. The proportion of tilled to the untilled area is about 1:2 or even higher $[9,10]$. Modern field crop production technologies and modern machinery have made it possible to till strips in a single pass and apply fertilisers and sow seeds at the same time, in the method known as strip-till one-pass (ST-OP) [11,12]. The soil in loosened and fertilised strips is not excessively compacted, allows excess water to infiltrate, warms 
quickly, is nutrient-rich, and constitutes a seedbed with conditions conducive to root growth. Inter-rows are left untilled, making them buffer zones for the frequent changes in soil conditions that take place in the immediate vicinity of plants. Plant residues left on the surface reduce runoff, water evaporation from deeper layers, and erosion [13-15]. However, soil conditions cannot be significantly favourably varied in adjacent strips when the strips of loosened and untilled soil are narrow and narrowly spaced. By contrast, widely spacing the strips of tilled soil reduces the cultivation of plants of high plant densities and narrow row spacings, e.g., cereals. However, some machines are also designed to allow cereals to be cultivated using ST-OP technology including the use of paired-row sowing [16,17]. In this case, the rows of plants are not evenly spaced. The distance between adjacent rows in the strip of tilled soil is smaller, and between the rows in successive strips separated by the strip of untilled soil is greater [18,19]. However, compared to traditional row sowing, paired-row sowing changes plants and canopy parameters $[20,21]$. Changing the row spacing while maintaining the same sowing density requires a change in the distance between plants in a row. The spatial distribution of plants influences the microclimate in the canopy. The light conditions, the spectral composition of light-the share of blue, red, and far-red light-are subject to change [22,23]. Thermal conditions, air humidity, and the use of water and soil nutrients also change [24-26]. Competition and other interactions between plants vary in terms of the strength of the effect. Parameters related to sowing shape the morphology of plants, the structure, and architecture of the canopy, physiological processes, and productivity [27-30]. Plant density and row spacing will change, among other things, the leaf area index, ground cover, mean leaf angle, light interception, relative humidity, biomass, organ spreading, and orientation [31,32]. The development and structure of plants are also subject to change, including yield components and yield expressed by various indices, such as plant height, number of tillers per plant, spikelets per spike, grains per spike, biological yield, and grain and straw yield [33,34].

This research was undertaken mainly in light of the dominance of cereals in the global food strategy, their cultivated area [35], the dynamic growth of conservation agriculture and resulting necessity to introduce non-inversion tillage methods [36], and the use of zonal soil tillage in the cultivation of many plants sown in wide row spacing [37]. In view of results indicating the beneficial effect of strip-till on soil properties and the economic efficiency of plant production [38,39], it was hypothetically assumed that this technology could be widely applied to cereal cultivation. The paired-row sowing of wheat or barley in tilled strips affects the canopy, whose structure and internal conditions allow the same or greater crop yields to be attained as compared to ploughless tillage and sowing in rows with regular narrow spacing. The aim of this research was to evaluate the morphology, physiology, and productivity of winter wheat and spring barley plants and their canopies created by strip-till one-pass technology. The structure, conditions, and yields of such canopies were also compared against those of the same cereals cultivated using ploughless tillage.

\section{Materials and Methods}

\subsection{Research Location and Period}

The research was carried out in the years 2017/18-2019/20 at the Agro-Land Marek Różniak agricultural company in Śmielin $\left(53^{\circ} 09^{\prime} 04.0^{\prime \prime} \mathrm{N} ; 17^{\circ} 29^{\prime} 10.7^{\prime \prime} \mathrm{E} ; 93.8 \mathrm{~m}\right.$ a.s.l.), Kujawsko-Pomorskie Voivodeship, Poland. The company and its Research and Development Centre cooperate with the Department of Agronomy at the University of Technology and Life Sciences in Bydgoszcz. The experiments were carried out on sandy loam soilLuvisol [40] each year in a different part of the experimental field complex. The soil properties in the $0-20 \mathrm{~cm}$ layer in the subsequent years of research are presented in Table 1. According to the Köppen classification [41], the research area lies in a humid continental climate zone classified as Dfb (cold, without dry season, warm summer) and in a region with frequent rainfall shortages [42]. The average annual sum of precipitation in the area of field trials is below $500 \mathrm{~mm}$, and the average annual air temperature is about $8.0^{\circ} \mathrm{C}$. 
Monthly rainfall and air temperature during the research period and in the long term are presented in Table 2.

Table 1. Soil properties in the site of field experiments.

\begin{tabular}{cccc}
\hline Property & $\mathbf{2 0 1 7 / 2 0 1 8}$ & $\mathbf{2 0 1 8 / 2 0 1 9}$ & $\mathbf{2 0 1 9 / 2 0 2 0}$ \\
\hline Texture $(\%):$ & & & \\
sand $(2-0.05 \mathrm{~mm})$ & 52.3 & 50.5 & 47.8 \\
silt $(0.05-0.002 \mathrm{~mm})$ & 43.6 & 44.5 & 48.4 \\
clay $(<0.002 \mathrm{~mm})$ & 4.1 & 5.0 & 6.8 \\
\hline $\mathrm{pH}_{\mathrm{KCl}}$ & 6.41 & 6.17 & 9.17 \\
\hline Organic carbon $(\mathrm{g} \mathrm{C} / \mathrm{kg}$ soil) & 9.34 & 9.51 & 1.03 \\
\hline Total nitrogen $(\mathrm{g} \mathrm{N} / \mathrm{kg}$ soil) & 0.97 & 0.94 & \\
\hline Available nutrients: & & & 203.1 \\
phosphorus $(\mathrm{mg} \mathrm{P} / \mathrm{kg}$ soil) & 84.3 & 74.7 & 54.4 \\
potassium $(\mathrm{mg} \mathrm{K} / \mathrm{kg}$ soil) & 173.6 & 194.1 & 67.3 \\
magnesium $(\mathrm{mg} \mathrm{Mg} / \mathrm{kg}$ soil) & 54.9 &
\end{tabular}

Table 2. Meteorological conditions during the research period.

\begin{tabular}{ccccccccccc}
\hline Month & $\mathbf{2 0 1 7}$ & $\mathbf{2 0 1 8}$ & $\mathbf{2 0 1 9}$ & $\mathbf{2 0 2 0}$ & Many-Year & $\mathbf{2 0 1 7}$ & $\mathbf{2 0 1 8}$ & $\mathbf{2 0 1 9}$ & $\mathbf{2 0 2 0}$ & Many-Year \\
\hline \multicolumn{7}{c}{ Air Temperature ${ }^{\circ} \mathbf{C}$ ) } \\
\hline January & - & 0.8 & -0.7 & 2.6 & -1.8 & - & 46.3 & 32.6 & 37.7 & 26.8 \\
February & - & -3.2 & 2.6 & 3.6 & -0.9 & - & 5.8 & 18.1 & 36.0 & 20.7 \\
March & - & -0.2 & 5.4 & 3.9 & 2.5 & - & 16.4 & 28.8 & 26.1 & 31.9 \\
April & - & 12.0 & 9.3 & 8.2 & 7.9 & - & 40.4 & 1.5 & 0.7 & 27.0 \\
May & - & 16.9 & 12.1 & 11.2 & 13.3 & - & 14.2 & 89.2 & 34.2 & 49.3 \\
June & - & 18.4 & 21.9 & 17.9 & 16.1 & - & 26.4 & 17.7 & 142.0 & 52.8 \\
July & - & 20.5 & 18.6 & 18.3 & 18.6 & - & 86.0 & 22.4 & 67.2 & 69.8 \\
August & - & 19.9 & 19.7 & 19.9 & 17.9 & - & 23.7 & 37.7 & 114.4 & 62.6 \\
September & 13.0 & 15.6 & 13.5 & - & 13.1 & 78.4 & 17.0 & 98.5 & - & 46.0 \\
October & 10.1 & 9.8 & 9.8 & - & 8.2 & 106.8 & 34.1 & 35.9 & - & 31.5 \\
November & 4.5 & 4.5 & 5.5 & - & 2.9 & 30.5 & 7.2 & 69.6 & - & 32.4 \\
December & 2.0 & 2.0 & 2.7 & - & -0.6 & 38.8 & 50.3 & 21.1 & - & 34.0 \\
\hline Average/Sum & - & 9.8 & 10.0 & - & 8.1 & - & 367.8 & 473.1 & - & 484.8 \\
\hline
\end{tabular}

\subsection{Field Experiments}

Two three-year field experiments were set up in a randomised block layout in triplicate and located side by side in a single field. The pre-crop was maize after grain harvest. In the first experiment, winter wheat was grown, and in the second, spring barley. The experimental units were plots of $150 \mathrm{~m}$ long and $12 \mathrm{~m}$ wide. Each experiment compared two technologies (experiment treatments) of non-inversion soil tillage, basic fertilisation, and sowing:

(i) ploughless tillage of the entire soil surface, the basic application of mineral fertilisers, seedbed preparation, and row sowing (PL-ES);

(ii) simultaneous deep loosening of soil strips, application of mineral fertilisers into loosened soil strips, paired-row sowing, i.e., strip-till one-pass (ST-OP).

In both experiments, the basic agrotechnical practices for PL-ES were conducted using 20-cm-deep tillage with a Horsch Tiger 6 AS cultivator; fertiliser application with an Amazone ZG-TS 8200; and seedbed preparation and sowing with a Horsch Pronto 4DC. The cereal row spacing was $14.3 \mathrm{~cm}$. In the ST-OP technology, soil strips of about $12 \mathrm{~cm}$ wide and $20 \mathrm{~cm}$ deep and an inter-spacing of $24 \mathrm{~cm}$ were tilled; fertilisers were applied to the loosened soil and paired-row sowing was performed, all in a single pass of a Mzuri-Pro Til 4T. The rows of plants within a single strip of tilled soil were spaced $12 \mathrm{~cm}$ from one 
another, and the distance to the next adjacent row (in the next strip) was $24.4 \mathrm{~cm}$. The scheme of soil cultivation and arrangement of plant rows for the two technologies is shown in Figure 1. Winter wheat was sown in the following years, 14, 10, and 18 October, in the density of 300 grains $/ \mathrm{m}^{2}$. Spring barley sowing parameters were respectively; 4, 8 April, and 23 March, 250 grains $/ \mathrm{m}^{2}$. In the cultivation of winter wheat (cv. Apostel), regardless of technology, $356 \mathrm{~kg} / \mathrm{ha}$ of NPK was used, including N-27 kg/ha, $\mathrm{P}_{2} \mathrm{O}_{5}-69 \mathrm{~kg} / \mathrm{ha}, \mathrm{K}_{2} \mathrm{O}-120$ $\mathrm{kg} /$ ha directly before sowing. Nitrogen (N-27 kg/ha) and phosphorus were applied only to the strips of loosened soil during tillage and sowing in the ST-OP technology, and, in the PL-ES technology, to the entire surface before seedbed preparation. Spring barley (cv. KWS Atrika), was fertilised with NPK $274 \mathrm{~kg} / \mathrm{ha}$ and in the following amounts directly before sowing: $\mathrm{N}-18 \mathrm{~kg} / \mathrm{ha}, \mathrm{P}_{2} \mathrm{O}_{5}-46 \mathrm{~kg} / \mathrm{ha}$, and $\mathrm{K}_{2} \mathrm{O}-90 \mathrm{~kg} / \mathrm{ha}$. In both experiments, the full dose of potassium was applied to the entire field area after harvesting the pre-crop. The presence of weeds and diseases was controlled chemically. The active ingredients of the herbicides were diflufenican, prosulfocarb, and fenoxaprop-P-ethyl for wheat; and MCPA and dicamba for spring barley. The active ingredients of the fungicides were prothioconazole, bixafen, spiroxamine and tebuconazole for wheat; and fenpropimorph, epoxiconazole, and metconazole for barley. Pests were only treated by intervention in 2018 and 2020 using an insecticide (deltamethrin). All crop protection materials were applied in accordance with current recommendations and instructions.

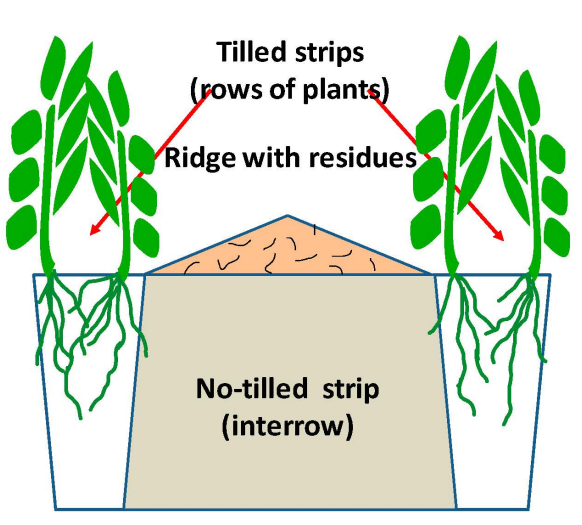

A

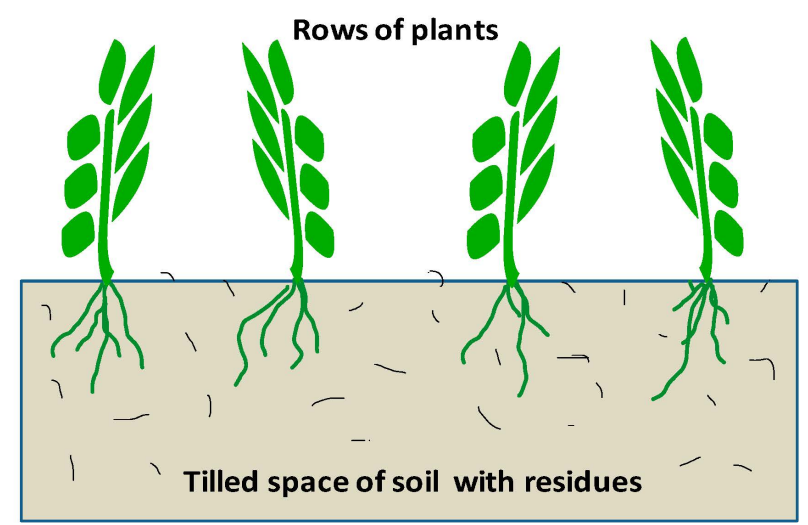

B

Figure 1. Schema soil tillage and cereals sowing in ST-OP (A) and PL-ES technologies (B).

\subsection{Sampling and Measurement}

On each plot, five measurement points were marked along a diagonal. After emergence, plant density (per $\mathrm{m}^{2}$ ) was determined, and in the later development stage, (BBCH 89) spike density and plant height were determined for 20 plants. At these points, 20 spikes were collected and the average number of grains per spike and grain weight per spike were determined. At each point, photosynthetically active radiation (PAR) was measured and the leaf area index (LAI) was determined during the BBCH 31-32 and BBCH 61 stages. In the canopy of cereals grown by PL-ES technology, measurements were taken in two configurations with respect to plant rows, i.e., in the inter-rows (narrow inter-row) along the rows of plants (IR-N) and perpendicular to the plant rows (R-PD). In the ST-OP technology, measurements were taken in three configurations, i.e., in the narrow inter-row between the two adjacent rows of a single strip of tilled soil (IR-N), in the wide, untilled inter-row between the rows of plants of two adjacent strips of tilled soil (IR-W), and perpendicular to plant rows (R-PD). Measurements were taken using an AccuPAR LP-80 PAR/LAI meter (METER Group, Inc., Pullman, WA, USA). Intercepted photosynthetic active radiation (IPAR\%) was calculated using PAR measurements above the cereal canopy and within the canopy, near the soil surface. At analogous times and locations in the canopy, on the upper fully formed leaves, stomatal conductance was assessed using an SC-1 Leaf Porometer 
(METER Group, Inc., Pullman, WA, USA). Results are expressed as $\mathrm{mmol}_{2} \mathrm{O} / \mathrm{m}^{2} / \mathrm{s}$. These leaves' chlorophyll content was also determined. Measurements were taken using a CM1000 "point-and-shoot" chlorophyll content meter (Spectrum Technologies, Inc., Aurora, IL, USA). At full-plant maturity (BBCH 89), the grain yield was harvested. It is expressed in $t /$ ha at $15 \%$ water content. The thousand-grain weight was determined on an averaged sample of grain yield from each plot. All measurements and assessments were performed analogously in the two experiments—-for winter wheat and spring barley.

\subsection{Data Analysis}

In each year of research, the uniformity of plant density over a large area of the experimental field (0.54 ha), depending on the technology of soil tillage and sowing, was determined. The uniformity was determined on the basis of plant density variability in 15 points for each treatment (three replications, five measurement points). The standard error (SE), standard deviation (s), deviating and extreme values were adopted as measures of variability. The results of the analysis are presented as a box-and-whiskers plot. The results of biometric and physiological measurements taken within the experimental treatments were analysed statistically. The distribution of the results of individual features was assessed assuming that variables were normally distributed. This hypothesis was verified using the Shapiro-Wilk test. Normally distributed data were subjected to ANOVA. The statistical significance of the influence of the experimental treatments was assessed with the F-test and the significance of differences between mean values of individual features with the post hoc Tukey's test at $p<0.05$. Because the impact of treatments on plant characteristics did not differ between successive years (insignificant interaction between treatment and years), the average results from the three research years were presented. The only influence of technology that differed between years was seen in intercepted photosynthetic active radiation (IPAR\%) in the winter wheat and barley canopies. Therefore, in addition to the average results, the results of individual crop cereal growing seasons are also presented.

The statistical analysis of results was performed in Statistica.PL 12 [43].

\section{Results}

The plant density of winter wheat plants in each of the three growing seasons did not differ significantly between the two technologies, although in 2018/19, there were 14.1 plants per $\mathrm{m}^{2}$ more in the ST-OP technology than in the PL-ES technology. In each season, especially in 2018/19, plant density immediately after emergence was more uniform (less variable) under ST-OP than under PL-ES (Figure 2A). The standard deviation of plant density was then 6.9 plants $/ \mathrm{m}^{2}$ and 27.6 plants $/ \mathrm{m}^{2}$, respectively. The plant density of spring barley in 2019 was 10.9 plants $/ \mathrm{m}^{2}$ higher under ST-OP than under PL-ES, and 15.2 plants $/ \mathrm{m}^{2}$ higher in 2020. Plant density in the experimental field was also less variable under ST-OP, as confirmed by its lower standard deviation. For the ST-OP and PL-ES technologies, respectively, this was 7.4 plants $/ \mathrm{m}^{2}$ and 17.2 plants $/ \mathrm{m}^{2}$ in 2019 , and 7.1 plants $/ \mathrm{m}^{2}$ and 20.7 plants $/ \mathrm{m}^{2}$ in 2020 (Figure $2 \mathrm{~B}$ ).

Plant morphology and spikelet density reacted similarly to the tillage and sowing method for both winter wheat and spring barley (Table 3). Winter wheat and spring barley plants grown under ST-OP technology were significantly shorter but had more grains per spike than those grown under PL-ES technology. Spike density was also significantly greater, and spikes had a higher grain weight. The technology did not affect the thousandgrain weight of either cereal species. 

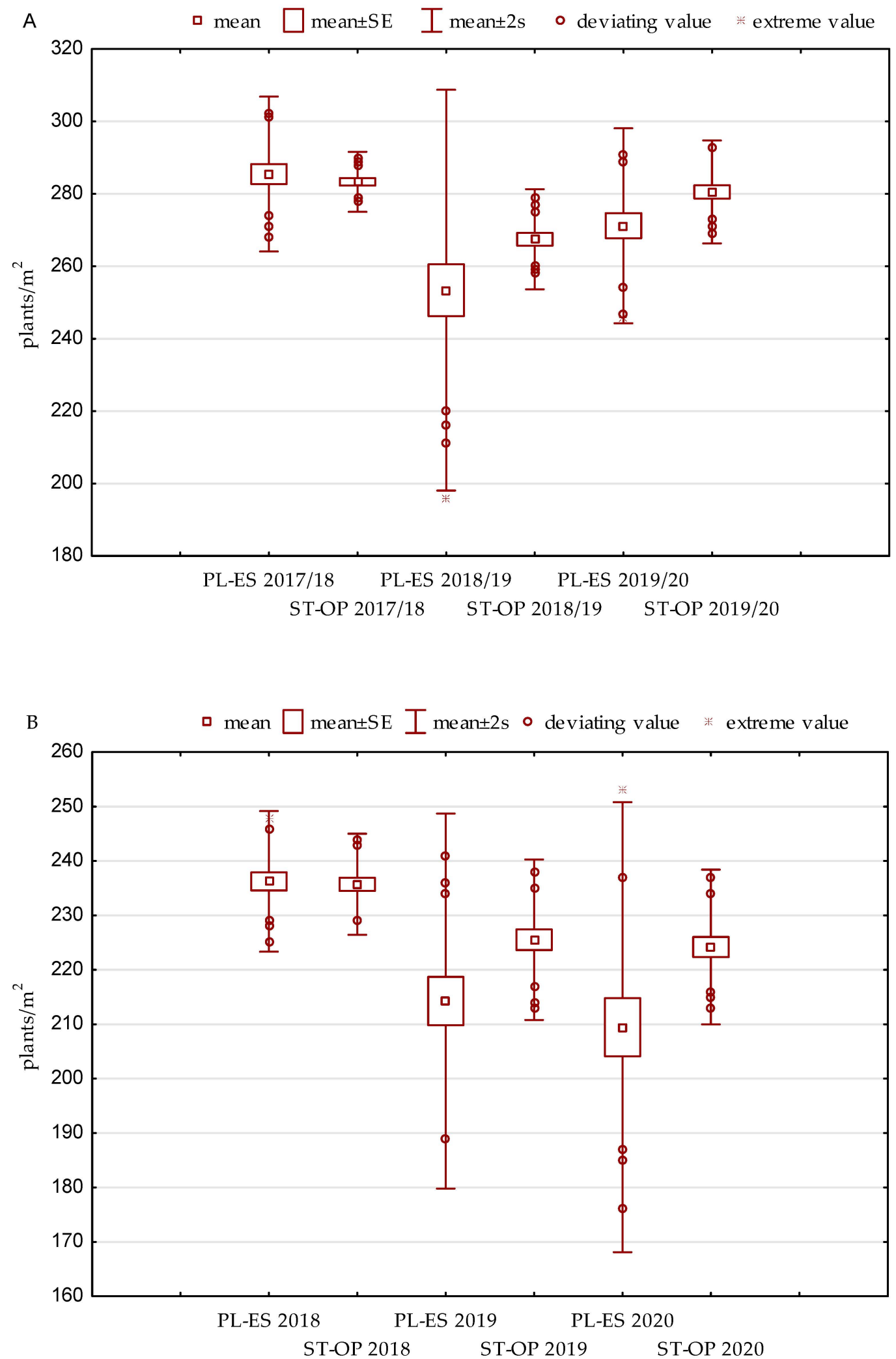

Figure 2. Variation in plant density of winter wheat (A) and spring barley (B) depending on the technology in the years of research; PL-ES: ploughless tillage, fertilisers, seedbed preparation, row sowing; ST-OP: deep loosening of soil strips, fertilisers into loosened soil strips, paired-row sowing. 
Table 3. Plant morphological features and yield components depending on the technology; PL-ES: ploughless tillage, fertilisers, seedbed preparation, row sowing; ST-OP: deep loosening of soil strips, fertilisers into loosened soil strips, paired-row sowing.

\begin{tabular}{ccccc}
\hline \multirow{2}{*}{ Feature } & \multicolumn{2}{c}{ Winter Wheat } & \multicolumn{2}{c}{ Spring Barley } \\
\cline { 2 - 5 } & PL-ES & ST-OP & PL-ES & ST-OP \\
\hline Plant height $(\mathrm{cm})$ & $91.5 \mathrm{a}$ & $88.4 \mathrm{~b}$ & $65.1 \mathrm{a}$ & $62.7 \mathrm{~b}$ \\
Spike density $\left(\right.$ no $\left./ \mathrm{m}^{2}\right)$ & $540.1 \mathrm{~b}$ & $572.7 \mathrm{a}$ & $641.6 \mathrm{~b}$ & $679.3 \mathrm{a}$ \\
Grains per spike & $34.8 \mathrm{~b}$ & $35.9 \mathrm{a}$ & $23.8 \mathrm{~b}$ & $25.3 \mathrm{a}$ \\
Grain weight per spike $(\mathrm{g})$ & $1.57 \mathrm{~b}$ & $1.64 \mathrm{a}$ & $1.05 \mathrm{~b}$ & $1.12 \mathrm{a}$ \\
Thousand grain weight $(\mathrm{g})$ & $44.4 \mathrm{~ns}$ & $44.6 \mathrm{~ns}$ & $43.6 \mathrm{~ns}$ & $43.9 \mathrm{~ns}$ \\
\hline
\end{tabular}

$\mathrm{a}, \mathrm{b}$ letters in rows (separately for winter wheat and spring barley) indicate significant difference at $p<0.05$; ns: insignificant difference.

The tillage and sowing technology, which determined plant distribution in the canopy, significantly influenced the leaf area index (Table 4). The LAI of winter wheat in the BBCH 32 stage along the rows of plants in narrow inter-rows (IR-N) was determined to be similar for each of the two technologies. Under ST-OP, the LAI was significantly smaller in the wide inter-row (IR-W). The LAI index determined perpendicular to the row direction (R-PD) in the canopy did not vary significantly between technologies, and under PL-ES, the same value did not differ from the value in the IR-N inter-rows. By contrast, under ST-OP, the R-PD LAI value was significantly smaller than the narrow rows (IR-N) LAI value (decrease by 0.43 ), and higher (increase by 0.96 ) than in the wide inter-rows in the strips of untilled soil (IR-W). During the flowering stage of BBCH 61 winter wheat, the LAI value was highest, regardless of tillage and sowing technology, in the immediate vicinity of the IR-N rows, while it was lower perpendicular to the rows (R-PD), and lowest in the IR-W zone under ST-OP. LAI was found to exhibit the same relationship with the point of evaluation in spring barley in the $\mathrm{BBCH} 31$ stage. In the later stage of spring barley development of BBCH 61, the LAI index in the PL-ES canopy was assessed to be 0.15 smaller perpendicular to rows (R-PD) than along the narrow rows (IR-N); and under ST-OP LAI was 0.23 smaller in the wide inter-row spaces (IR-W) than either along the rows in the tilled strip (IR-N) or perpendicular to sowing direction (R-PD)—reduction by o 0.13 .

Table 4. The LAI value depending on the technology; PL-ES: ploughless tillage, fertilisers, seedbed preparation, row sowing; ST-OP: deep loosening of soil strips, fertilisers into loosened soil strips, paired-row sowing.

\begin{tabular}{cccccc}
\hline \multirow{2}{*}{ BBCH Stage } & \multicolumn{3}{c}{ PL-ES } & ST-OP \\
\cline { 2 - 6 } & IR-N & R-PD & IR-N & IR-W & R-PD \\
\hline \multicolumn{5}{c}{ Winter wheat } \\
\hline 32 & $2.01 \mathrm{ab}$ & $1.83 \mathrm{bc}$ & $2.09 \mathrm{a}$ & $0.70 \mathrm{~d}$ & $1.66 \mathrm{c}$ \\
61 & $4.65 \mathrm{a}$ & $4.22 \mathrm{~b}$ & $4.73 \mathrm{a}$ & $3.58 \mathrm{c}$ & $4.19 \mathrm{~b}$ \\
\hline \multicolumn{7}{c}{ Spring barley } \\
\hline 61 & $1.79 \mathrm{a}$ & $1.64 \mathrm{~b}$ & $1.85 \mathrm{a}$ & $0.85 \mathrm{c}$ & $1.52 \mathrm{~b}$ \\
& $3.53 \mathrm{a}$ & $3.38 \mathrm{bc}$ & $3.51 \mathrm{a}$ & $3.28 \mathrm{c}$ & $3.41 \mathrm{ab}$ \\
\hline
\end{tabular}

$\mathrm{a}, \mathrm{b}, \mathrm{c}$ letters in rows (separately for technologies) indicate significant difference; IR-N: narrow inter-row; R-PD: perpendicular to the plant rows; IR-W: wide inter-row.

The light conditions in different places of the canopy crops grown under PL-ES and ST-OP differed between study years (Table 5). In the first two years, the IPAR index in the canopy of winter wheat and spring barley in PL-ES technology was significantly higher along rows (IR-N) than perpendicular to rows (R-PD) regardless of stage $\mathrm{BBCH}$. The case was similar in the 2019/20 season. Under ST-OP technology, the IPAR index along with the IR-N rows and perpendicular to them (R-PD) was found to be similar only in the BBCH 61 stage of the spring barley canopy in 2018 and 2020. Only in this last canopy (spring barley 2020) was there a similar IPAR value in the wide inter-rows 
of the untilled strip IR-W. On average, during the research period, it was found that in the earlier development stages (BBCH 31-32) of both cereal species the IPAR under ST-OP was significantly lower in wide inter-rows (IR-W) than in narrow inter-rows (IR-N) and perpendicular to rows (R-PD). The difference in the value of the IPAR index for winter wheat was $21.9 \%$ and $13.0 \%$, respectively, and for spring barley, $21.4 \%$ and $15.4 \%$ (Table 5). The IPAR in the canopy of winter wheat in the BBCH 61 stage was highest along narrow rows (IR-N), especially under ST-OP. Under PL-ES, it did not differ from the index determined perpendicular to rows (R-PD). Under the ST-OP technology, the IPARs in wide rows (IR-W) and perpendicular to row direction (R-PD) were significantly smaller than between the narrow rows of plants in the tilled strip (IR-N). The difference was $8.0 \%$ and $3.3 \%$, respectively. In the canopy of spring barley grown under PL-ES, the IPAR index was found to be $3.7 \%$ higher along narrow rows (IR-N) than perpendicular to them (R-PD). Under ST-OP, the IPAR index in narrow inter-rows (IR-N) and perpendicular to the rows (R-PD) was similar to corresponding places in the PL-ES canopy, while also being significantly higher than in the untilled strip, i.e., the wide inter-rows (IR-W) 一an increase by $4.4 \%$ and $2.9 \%$, respectively.

Table 5. The intercepted photosynthetic active radiation (IPAR\%) value depending on the technology in the years of research; PL-ES: ploughless tillage, fertilisers, seedbed preparation, row sowing; ST-OP: deep loosening of soil strips, fertilisers into loosened soil strips, paired-row sowing.

\begin{tabular}{|c|c|c|c|c|c|}
\hline \multirow{2}{*}{ ВBCH Stage } & \multicolumn{2}{|c|}{ PL-ES } & \multicolumn{3}{|c|}{ ST-OP } \\
\hline & IR-N & R-PD & IR-N & IR-W & R-PD \\
\hline \multicolumn{6}{|c|}{ Winter wheat-2017/18 } \\
\hline 32 & $79.8 \mathrm{a}$ & $74.8 \mathrm{~b}$ & $80.3 \mathrm{a}$ & $47.4 \mathrm{~d}$ & $70.3 c$ \\
\hline 61 & $92.9 \mathrm{a}$ & $88.8 \mathrm{~b}$ & $95.1 \mathrm{a}$ & $85.5 \mathrm{c}$ & $86.9 \mathrm{bc}$ \\
\hline \multicolumn{6}{|c|}{ Spring barley-2018 } \\
\hline 31 & $78.2 \mathrm{a}$ & $70.9 \mathrm{~b}$ & $77.6 \mathrm{a}$ & $54.6 \mathrm{c}$ & $69.2 \mathrm{~b}$ \\
\hline 61 & $87.1 \mathrm{a}$ & $83.4 \mathrm{c}$ & $86.3 \mathrm{ab}$ & $82.4 \mathrm{c}$ & $84.5 \mathrm{bc}$ \\
\hline \multicolumn{6}{|c|}{ Winter wheat-2018/19 } \\
\hline 32 & $82.9 \mathrm{a}$ & $76.4 \mathrm{~b}$ & $83.2 \mathrm{a}$ & $68.9 \mathrm{~d}$ & $73.1 \mathrm{c}$ \\
\hline 61 & $95.6 \mathrm{a}$ & $92.0 \mathrm{~b}$ & $96.4 \mathrm{a}$ & $88.6 \mathrm{c}$ & $92.7 \mathrm{~b}$ \\
\hline \multicolumn{6}{|c|}{ Spring barley-2019 } \\
\hline 31 & $79.5 \mathrm{a}$ & $76.6 \mathrm{bc}$ & $77.8 \mathrm{ab}$ & $55.8 \mathrm{~d}$ & $74.9 \mathrm{c}$ \\
\hline 61 & $91.3 \mathrm{a}$ & $87.4 \mathrm{bc}$ & $89.9 \mathrm{ab}$ & $83.8 \mathrm{~d}$ & $85.1 \mathrm{~cd}$ \\
\hline \multicolumn{6}{|c|}{ Winter wheat-2019/20 } \\
\hline 32 & $83.3 \mathrm{ab}$ & $80.6 \mathrm{bc}$ & $85.1 \mathrm{a}$ & $66.8 \mathrm{~d}$ & $78.7 \mathrm{c}$ \\
\hline 61 & $92.3 \mathrm{ab}$ & $91.6 \mathrm{bc}$ & $93.2 \mathrm{a}$ & $86.7 \mathrm{~d}$ & $90.9 c$ \\
\hline \multicolumn{6}{|c|}{ Spring barley-2020 } \\
\hline 31 & $78.4 \mathrm{ab}$ & $77.3 \mathrm{ab}$ & $81.1 \mathrm{a}$ & $62.2 \mathrm{c}$ & $74.5 \mathrm{~b}$ \\
\hline 61 & $86.3 \mathrm{a}$ & $83.2 \mathrm{ab}$ & $85.2 \mathrm{ab}$ & $82.0 \mathrm{~b}$ & $84.1 \mathrm{ab}$ \\
\hline \multicolumn{6}{|c|}{ Winter wheat-2017/18-2019/20 } \\
\hline 32 & $82.0 \mathrm{a}$ & $77.3 \mathrm{a}$ & 82.9 a & $61.0 \mathrm{~b}$ & $74.0 \mathrm{a}$ \\
\hline 61 & $93.6 \mathrm{ab}$ & $90.8 \mathrm{~b}$ & $94.9 \mathrm{a}$ & $86.9 c$ & $90.2 \mathrm{bc}$ \\
\hline \multicolumn{6}{|c|}{ Spring barley-2018-2020 } \\
\hline 31 & $76.7 \mathrm{a}$ & $74.9 \mathrm{ab}$ & $78.9 \mathrm{a}$ & $57.5 \mathrm{c}$ & $72.9 \mathrm{~b}$ \\
\hline 61 & $88.2 \mathrm{a}$ & $84.5 \mathrm{bc}$ & $87.1 \mathrm{ab}$ & $82.7 \mathrm{c}$ & $85.6 \mathrm{ab}$ \\
\hline
\end{tabular}

$\mathrm{a}, \mathrm{b}$, c letters in rows indicate significant difference; IR-N: narrow inter-row; R-PD: perpendicular to the plant rows; IR-W: wide inter-row.

The leaf stomatal conductance of winter wheat in the BBCH 61 stage was $18 \mathrm{mmol}$ $\mathrm{H}_{2} \mathrm{O} / \mathrm{m}^{2} / \mathrm{s}$ higher under ST-OP than under PL-ES technology (Figure 3). By contrast, the 
tillage and sowing method did not significantly differentiate the leaf stomatal conductance of winter wheat in the $\mathrm{BBCH} 32$ stem elongation stage. The leaf stomatal conductance of spring barley, both in the $\mathrm{BBCH} 31$ and $\mathrm{BBCH} 61$ stage, was significantly higher under ST-OP than under PL-ES technology. The difference was $19 \mathrm{mmol} \mathrm{H}_{2} \mathrm{O} / \mathrm{m}^{2} / \mathrm{s}$ and $18 \mathrm{mmol}$ $\mathrm{H}_{2} \mathrm{O} / \mathrm{m}^{2} / \mathrm{s}$, respectively.

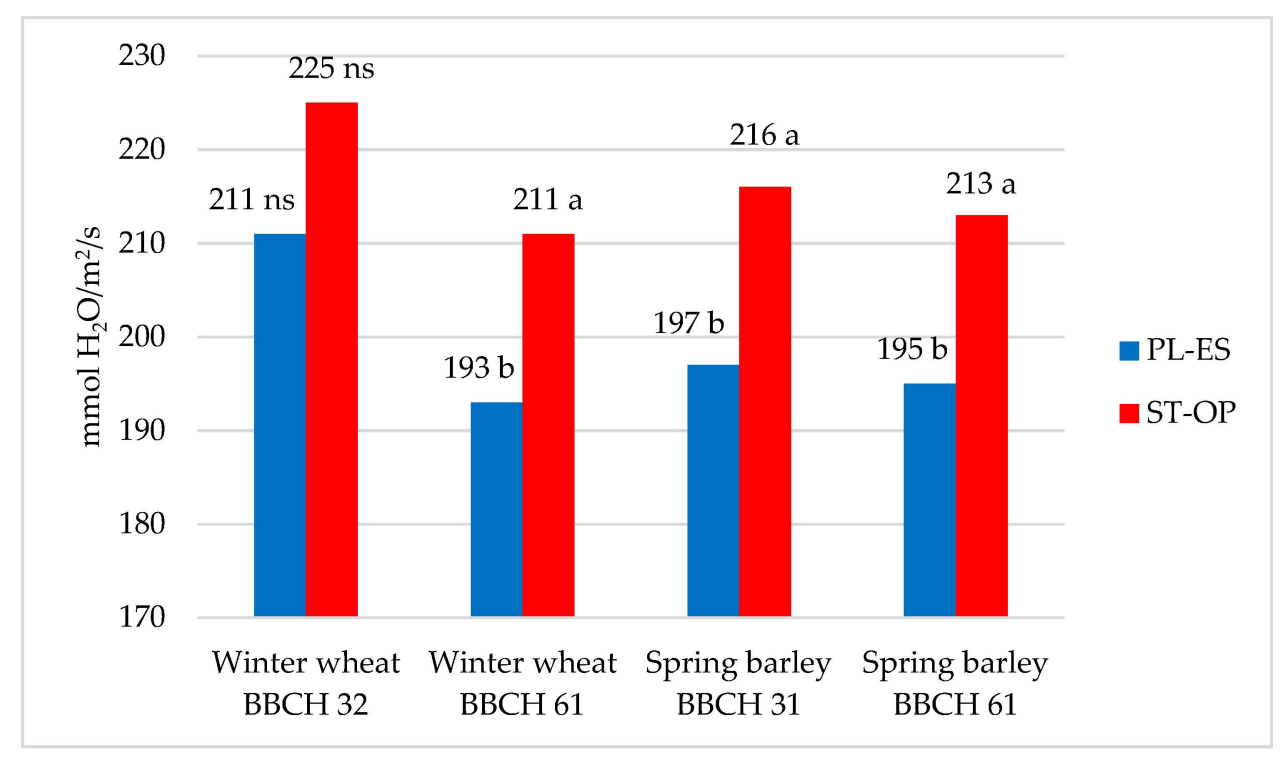

Figure 3. The leaf stomatal conductance of winter wheat and spring barley depending on the technology; PL-ES: ploughless tillage, fertilisers, seedbed preparation, row sowing; ST-OP: deep loosening of soil strips, fertilisers into loosened soil strips, paired-row sowing; $\mathrm{a}, \mathrm{b}$ letters indicate significant difference at $p<0.05$ for individual cereals in a given $\mathrm{BBCH}$ stage; ns: insignificant difference.

Leaves of winter wheat cultivated under ST-OP technology contained significantly more chlorophyll than wheat leaves grown under PL-ES, in both the BBCH 32 (increase by 43 units) and $\mathrm{BBCH} 61$ stage-an increase by 39 units (Figure 4). In both growth stages, the chlorophyll content of spring barley leaves, too, was higher under ST-OP than PL-ES technology.

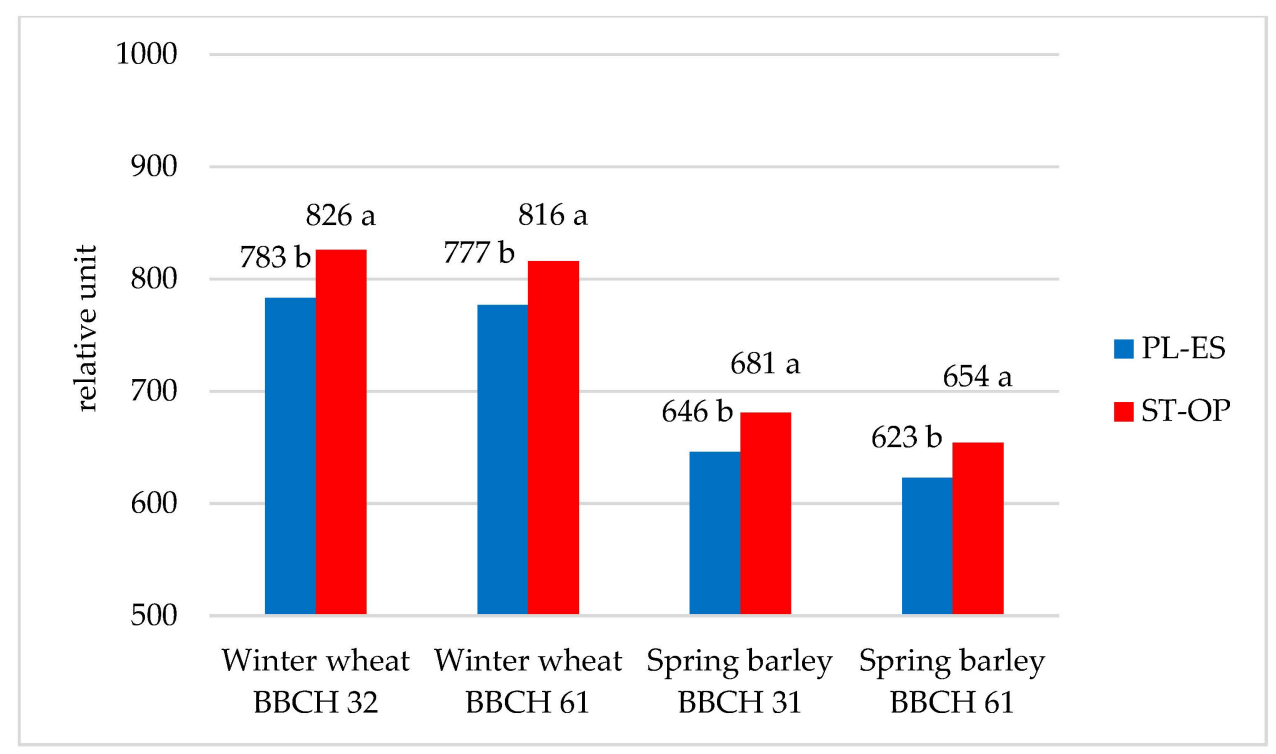

Figure 4. Chlorophyll content in leaves of winter wheat and spring barley depending on the technology; PL-ES: ploughless tillage, fertilisers, seedbed preparation, row sowing; ST-OP: deep loosening of soil strips, fertilisers into loosened soil strips, paired-row sowing; $a$, b letters indicate significant difference at $p<0.05$ for individual cereals in a given $\mathrm{BBCH}$ stage. 
The grain yield of winter wheat grown was $0.43 \mathrm{t} / \mathrm{ha}$ higher under ST-OP than PL-ES (Figure 5). The increase in yield of spring barley grain as a result of cultivation under strip tillage and paired-row sowing, as compared to ploughless entire-surface tillage, row sowing, was $0.52 \mathrm{t} / \mathrm{ha}$.

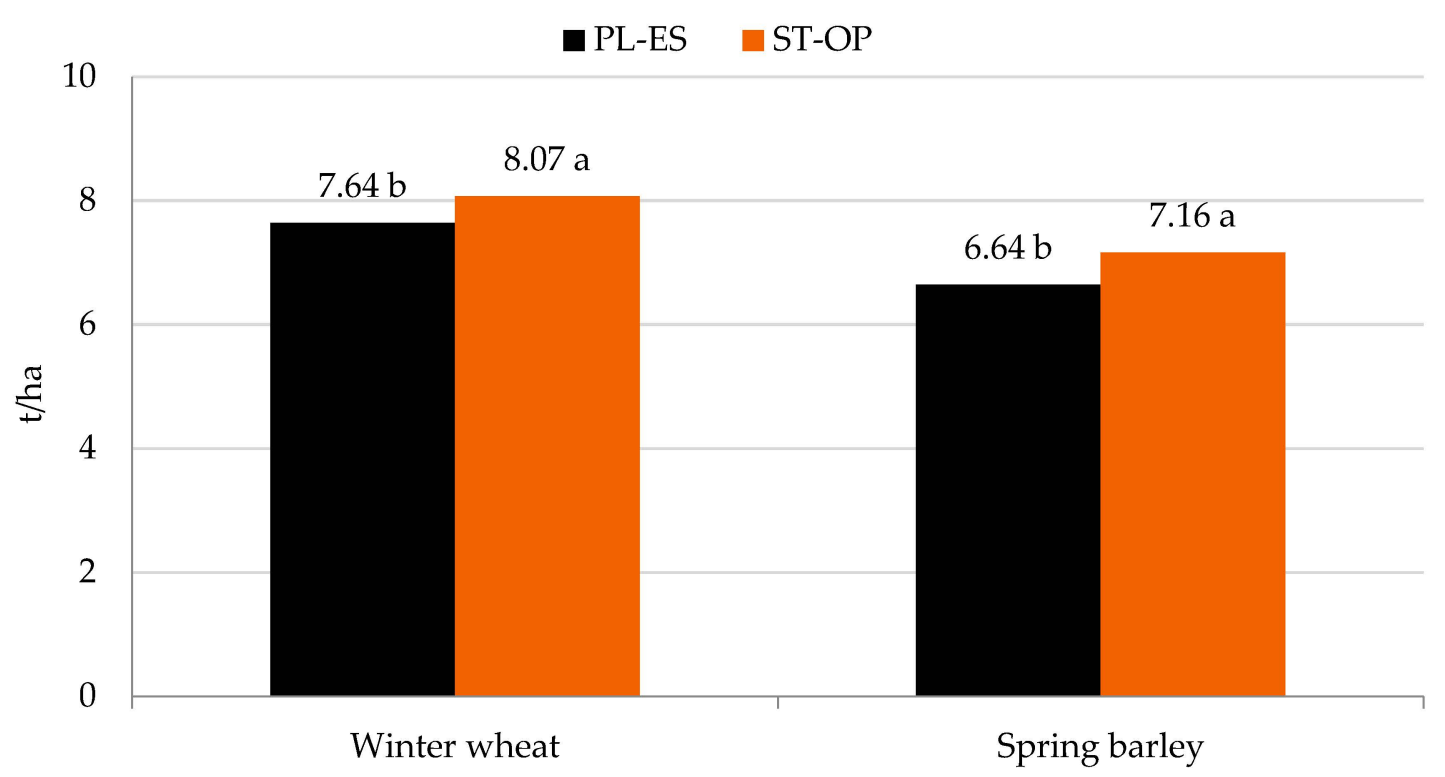

Figure 5. Winter wheat and spring barley yields depending on the technology; PL-ES: ploughless tillage, fertilisers, seedbed preparation, row sowing; ST-OP: deep loosening of soil strips, fertilisers into loosened soil strips, paired-row sowing; $\mathrm{a}, \mathrm{b}$ letters indicate significant difference at $p<0.05$ for individual cereals.

\section{Discussion}

Strip-till one-pass with paired-row sowing allows for cereal yields equal to or higher than conventional or ploughless tillage and sowing in narrowly spaced rows. This hypothesis is confirmed by the present results and the results of the authors' previous research and other studies in various regions of the world [44]. In the present study, the yield of winter wheat cultivated under ST-OP was 5.6\% greater than the yield under PL-ES. The increase in spring barley yield was $7.8 \%$. The authors' previous studies found that replacing reduced, ploughless tillage and row sowing with ST-OP increased the winter barley yield by $6.4-7.7 \%$ [45], and the winter wheat yield by $6.1-10.4 \%$ [46]. The results of studies by other authors also show that strip-till may increase wheat yields as compared to other cultivation methods $[47,48]$. The high cereal yields may derive from the beneficial effect that strip-tillage has on soil properties, a border effect, and the microclimate in the canopy. Tilling narrow strips with mulching in inter-rows reduces water loss and increases its production efficiency [49-51]. Meanwhile, plants adjacent to wide inter-rows achieve greater dimensions and weight than inside the canopy [52].

Strip till is particularly effective in regions or periods of rainfall deficits. Soil moisture, and soil temperatures of up to $2-3^{\circ} \mathrm{C}$ higher in loosened strips than in untilled soil, create conditions conducive to quick and uniform plant emergence [53,54]. In the authors' own research, the sufficiency of water in the soil after sowing winter wheat in 2018 and spring barley in 2019 and 2020 was probably the main reason for the higher-and, above all, more uniform-density of cereals grown under ST-OP. In April 2019 and 2020, after sowing spring barley, there was only $1.5 \mathrm{~mm}$ and $0.7 \mathrm{~mm}$, respectively, of rainfall. Strip tillage-and particularly ST-OP, which reduces the number of agrotechnological treatments interfering in the soil-creates habitat conditions favourable to crops during the germination and emergence stages and throughout the growing season. The cereals' good supply of water in the authors' experiments in a region and years of low rainfall was confirmed by the leaf stomatal conductance of winter wheat and spring barley. This index was significantly 
higher under ST-OP than PL-ES for both investigated cereals. This difference was found at various development stages in all years of the research, which was indicated by the lack of a significant interaction between treatment and year. The beneficial effect of strip-tillage or STOP technology applies to water conditions and to other physical, chemical, and biological properties of the soil. This technology buffers' sudden changes in air and water conditions reduce soil erosion and degradation of organic matter and activate soil organisms, while localised starter fertilisation facilitates plant roots' access to nutrients $[49,55,56]$. These conditions are appropriate for the formation of good-condition crop canopies with high production potential. In previous studies [57], the authors analysed 44 features, found a beneficial effect of the ST-OP technology on the chemical and biological properties of soil. After eight years of successive cultivation of plants in this technology, the content of nutrients has increased. The number of soil organisms and the activity of enzymes were also higher compared to conventionally tilled soil. For example, the content of available potassium increased by $13.0 \%$, the number of earthworms four-fold, and the activity of alkaline phosphatase by $23.0 \%$. The yield of winter rape was $7.8 \%$ higher than that of conventional soil tilling.

The crop canopy forms from the initial to late development stages. The conditions for a uniform crop canopy are correct sowing method and uniform, fast emergence [58,59]. Plants that are equally advanced in development enable effective and safe agrotechnological treatments, especially for plant protection and harvesting [60]. In the authors' earlier studies [45,61] and the present study, the compared soil tillage and sowing methods yielded differences in the spatial distribution of plants. Under ST-OP, apart from the narrow plant row spacing typical of cereals, there was also an inter-spacing of twice as wide, i.e., about $24 \mathrm{~cm}$. These wide inter-rows allowed light to better penetrate to the bottom of the canopy. This light penetration into the lower canopy layers is confirmed by the lower LAI and IPAR values in the wide inter-rows compared to those measured in the narrow inter-rows under ST-OP or the inter-rows under PL-ES. This difference was maintained even in the later stages of intensive vegetative biomass growth and flowering (BBCH 61). The spectral composition of non-scattered light has a smaller share of red and far-red light. Long-wave light strongly affects plant photomorphogenesis, including shoot elongation. According to Goins et al. [62], when exposed to red light, wheat produced longer leaves and shoots, but 2.5 -fold lower yield than under white light. The addition of blue light to red light resulted in greater productivity that was comparable to the accumulation of shoot dry mass and grain yield obtained under the influence of white light. According to Sparkes and King [63], light quality (red:far-red (R:FR)) is responsible for lodging the wheat canopy. The lower share of red and far-red light in the light penetrating the cereal canopies in the wide interrows was the main reason for the shorter tillers of the shorter plants grown under ST-OP. However, this should be considered a favourable agricultural feature because shorter plants are less prone to lodging. The conditions in such a canopy are also less conducive to the growth of fungal pathogens $[64,65]$. In the conducted research, the winter wheat and spring barley canopies were heavily protected against disease with the use of 2-3 fungicides. The evaluation of pathogens showed a low presence and no dependence on technology. The results are thus not presented in the paper. Penetration and interception of light by the canopy, especially in later development stages, increases plant productivity and building of yield components, and in the initial stages stimulates the formation of productive tillers and limits their reduction $[66,67]$. This reaction of cereals to light conditions in the canopy may partially explain why, in both winter wheat and spring barley, in the rows of plants with different spacings under ST-OP, the number of spikes was greater, and the spikes had higher grain numbers and weight than under PL-ES, in which plants were only sown in narrowly spaced rows. However, the results of physiological and agricultural research show that the dependence of cereal productivity and yield on light conditions in the canopy is very complex and multifaceted. Generally, these parameters increase as LAI and PAR values increase, although these need not be simple linear relationships and they interact with environmental factors and agrotechnical treatments [68,69]. Elii et al. [70] showed 
that with increasing the nitrogen dose from $0 \mathrm{~kg} \mathrm{~N} / \mathrm{ha}$ to $160 \mathrm{~kg} \mathrm{~N} / \mathrm{ha}$, the LAI and SPAD indexes increased in various wheat cultivars, respectively, from 1.92 to 4.44 and from 37.93 to 49.51 . The higher productivity of cereals in our study may also have been caused by the good supply of nutrients, especially nitrogen. Under the ST-OP technology, the basic fertiliser dose is applied directly to the root growth zone-the strip of tilled soil. Furthermore, granules of nitrogen fertiliser used for top dressing largely accumulate near plant rows, in the "mini furrows" created during sowing [16]. The higher chlorophyll content in the winter wheat and spring barley, both in the BBCH 31-32 phase and in the later BBCH 61 stage, proves a good supply of nitrogen to the cereals (better than under PL-ES).

\section{Conclusions}

The architecture of the canopies of cereals grown under ST-OP is the result of narrow strips of soil being tilled and sown with two rows of plants. A multifunctional hybrid Mzuri Pro-Til 4T machine was used to create narrow strips of loosened soil (12-cm-wide) separated by double-width inter-rows of untilled soil. In the resultant canopy, the light conditions differ between the narrow and wide inter-rows. The LAI index lower by 1.15 in the wide row spacing (e.g., winter wheat in the BBCH 61 stage) resulted in a less light interception. The value of the IPAR index was lower by $8.0 \%$. More light reaches the bottom of the canopy. The canopies of winter wheat and spring barley cultivated by ST-OP technology had a 32.6-37.7 per $\mathrm{m}^{2}$ greater number of tillers with spike, $2.4-3.1 \mathrm{~cm}$ shorter plants, and 1.1-1.5 more grains per spike than those of the cereals cultivated in a narrow row spacing $(14.3 \mathrm{~cm})$ after ploughless soil tillage, i.e., PL-ES technology. The leaves of winter wheat and spring barley in the BBCH 61 stage in these fields contained 39 and 31 units more of chlorophyll, respectively, which may confirm favourable light conditions and indicate better nutrition, especially with nitrogen. The higher leaf stomatal conductance of winter wheat and spring barley by $18-19 \mathrm{mmol} \mathrm{H}_{2} \mathrm{O} / \mathrm{m}^{2} / \mathrm{s}$ suggests good water supply to the plants, despite the study having been conducted in an area and a period of low precipitation. The morphology, physiology, and productivity of plants indicate favourable habitat conditions, including soil and the microclimate of the cereal canopy, which are shaped by strip-till with simultaneous fertilising and sowing performed during a single pass of a machine. In the case of a precipitation deficit during the sowing period, they guarantee uniform plant density within the canopy. This technology is an alternative to other non-inversion tillage methods.

Author Contributions: Conceptualization I.J.; methodology, I.J. and D.J.; investigation-performed the field experiments I.J. and D.J.; data curation—compiled and analysed the results I.J.; writingoriginal draft preparation I.J.; review and editing-I.J. and D.J. All authors have read and agreed to the published version of the manuscript.

Funding: This research received no external funding.

Acknowledgments: The authors thank the company Agro-Land Marek Różniak at Śmielin, Poland, for allowing experimentation in their production field with the use of the strip-till hybrid machine Mzuri Pro-Til.

Conflicts of Interest: The authors declare no conflict of interest.

\section{References}

1. Porwollik, V.; Rolinski, S.; Heinke, J.; Müller, C. Generating a rule-based global gridded tillage dataset. Earth Syst. Sci. Data 2019, 11, 823-843. [CrossRef]

2. Kassam, A.; Friedrich, T.; Derpsch, R. Global spread of conservation agriculture. Int. J. Environ. Stud. 2019, 76, 29-51. [CrossRef]

3. Erb, K.H.; Luyssaert, S.; Meyfroidt, P.; Pongratz, J.; Don, A.; Kloster, S.; Kuemmerle, T.; Fetzel, T.; Fuchs, R.; Herold, M.; et al. Land management: Data availability and process understanding for global change studies. Glob. Chang. Biol. 2016, 23, 512-533. [CrossRef] [PubMed]

4. Townsend, T.J.; Ramsden, S.J.; Wilson, P. How do we cultivate in England? Tillage practices in crop production systems. Soil Use Manag. 2016, 32, 106-117. [CrossRef] [PubMed] 
5. Alskaf, K.; Sparkes, D.L.; Mooney, S.J.; Sjögersten, S.; Wilson, P. The uptake of different tillage practices in England. Soil Use Manag. 2020, 36, 27-44. [CrossRef]

6. Twizerimana, A.; Niyigaba, E.; Mugenzi, I.; Ngnadong, W.A.; Li, C.; Hao, T.Q.; Shio, B.J.; Hai, J.B. The Combined Effect of Different Sowing Methods and Seed Rates on the Quality Features and Yield of Winter Wheat. Agriculture 2020, 10, 153. [CrossRef]

7. Abdus-Subhan; Khan, Q.; Mansoor, M.; Khan, M.J.; Ammanullah; Khan, M. Response of Wheat to tillage and sowing techniques under arid condition. Pak. J. Agric. Res. 2017, 30, 136-143. [CrossRef]

8. Mitchell, J.P.; Carter, L.M.; Reicosky, D.C.; Shrestha, A.; Pettygrove, G.S.; Klonsky, K.M.; Marcum, D.B.; Chessman, D.; Royi, R.; Hogan, P.; et al. A history of tillage in California's Central Valley. Soil Tillage Res. 2016, 157, 52-64. [CrossRef]

9. Morris, N.L.; Miller, P.C.H.; Orson, J.H.; Froud-Williams, R.J. The adoption of noninversion tillage systems in the United Kingdom and the agronomic impact on soil, crops and the environment-A review. Soil Tillage Res. 2010, 108, 1-15. [CrossRef]

10. Benincasa, P.; Zorzi, A.; Panella, F.; Tosti, G.; Trevini, M. Strip tillage and sowing: Is precision planting indispensable in silage maize? Int. J. Plant Prod. 2017, 11, 577-588.

11. Morrison Jr, J.E.; Sanabria, J. One-pass and two-pass spring strip tillage for conservation row-cropping in adhesive clay soils. Trans. ASABE 2002, 45, 1263-1270. [CrossRef]

12. Mzuri. The Complete Strip Tillage System. Available online: http://mzuri.eu/wpcontent/uploads/MzuriBrochure-2017.pdf (accessed on 12 May 2020).

13. Williams, A.; Kane, D.A.; Ewing, P.M.; Atwood, L.W.; Jilling, A.; Li, M.; Lou, Y.; Davis, A.S.; Grandy, A.S.; Huerd, S.C.; et al. Soil functional zone management: A vehicle for enhancing production and soil eco-system services in row-crop agroecosystems. Front. Plant Sci. 2016, 7, 65. [CrossRef] [PubMed]

14. Fernández, F.G.; Sorensen, B.A.; Villamil, M.B. A comparison of soil properties after five years of no-till and strip-till. Agron. J. 2015, 107, 1339-1346. [CrossRef]

15. Laufer, D.; Loibl, B.; Märländer, B.; Koch, H.J. Soil erosion and surface runoff under strip tillage for sugar beet (Beta vulgaris L.) in Central Europe. Soil Tillage Res. 2016, 162, 1-7. [CrossRef]

16. Jaskulska, I.; Jaskulski, D. Strip-Till One-Pass Technology in Central and Eastern Europe: A MZURI Pro-Til Hybrid Machine Case Study. Agronomy 2020, 10, 925. [CrossRef]

17. Senger, M.; Zagonel, J.; Ferreira, C.; de Souza, A.C.; Zardo-Filho, R. Influence of wheat populations arrangement on growth characteristics and grain yield. Afr. J. Agric. Res. 2015, 10, 4937-4944.

18. Mao, X.M.; Zhong, W.W.; Wang, X.Y.; Zhou, X.B. Effects of precision planting patterns and irrigation on winter wheat yields and water productivity. J. Agric. Sci. 2017, 155, 1394-1406. [CrossRef]

19. Bellaloui, N.; Bruns, H.A.; Abbas, H.K.; Mengistu, A.; Fisher, D.K.; Reddy, K.N. Effects of Row-Type, Row-Spacing, Seeding Rate, Soil-Type, and Cultivar Differences on Soybean Seed Nutrition under US Mississippi Delta Conditions. PLoS ONE 2015, 10, e0129913. [CrossRef]

20. Zhou, X.B.; Wang, G.Y.; Yang, L.; Wu, H.Y. Double-Double Row Planting Mode at Deficit Irrigation Regime Increases Winter Wheat Yield and Water Use Efficiency in North China Plain. Agronomy 2020, 10, 1315. [CrossRef]

21. Bhunia, S.R.; Verma, I.M.; Arif, M.; Gochar, R.; Sharma, N.C. Effect of crop geometry, drip irrigation and bio-regulator on growth, yield and water use efficiency of wheat (Triticum aestivum L.). Int. J. Agric. Sci. 2015, 11, 45-49. [CrossRef]

22. Monostori, I.; Heilmann, M.; Kocsy, G.; Rakszegi, M.; Ahres, M.; Altenbach, S.B.; Szalai, G.; Pál, M.; Toldi, D.; Simon-Sarkadi, L.; et al. LED Lighting-Modification of growth, metabolism, yield and flour composition in wheat by spectral quality and intensity. Front. Plant Sci. 2018, 9, 605. [CrossRef] [PubMed]

23. Emmel, C.; D'Odorico, P.; Revill, A.; Hörtnagl, L.; Ammann, C.; Buchmann, N.; Eugster, W. Canopy photosynthesis of six major arable crops is enhanced under diffuse light due to canopy architecture. Glob. Chang. Biol. 2020, 26, 5164-5177. [CrossRef] [PubMed]

24. Barillot, R.; Chambon, C.; Fournier, C.; Combes, D.; Pradal, C.; Andrieu, B. Investigation of complex canopies with a functionalstructural plant model as exemplified by leaf inclination effect on the functioning of pure and mixed stands of wheat during grain filling. Ann Bot. 2019, 123, 727-742. [CrossRef]

25. Li, D.; Zhang, D.; Wang, H.; Li, H.; Fang, Q.; Li, H.; Li, R. Optimized planting density maintains high wheat yield under limiting irrigation in North China Plain. Int. J. Plant Prod. 2020, 14, 107-117. [CrossRef]

26. Pandey, B.; Basnet, K.; Bhatta, M.; Sah, S.; Thapa, R.; Kandel, T. Effect of row spacing and direction of sowing on yield and yield attributing characters of wheat cultivated in Western Chitwan, Nepal. J. Agric. Sci. 2013, 4, 309-316. [CrossRef]

27. Hussain, M.; Waqas-Ul-Haq, M.; Farooq, S.; Jabran, K.; Farroq, M. The impact of seed priming and row spacing on the productivity of different cultivars of irrigated wheat under early season drought. Exp. Agric. 2016, 52, 477-490. [CrossRef]

28. Hussain, M.; Khan, M.B.; Mehmood, Z.; Zia, A.B.; Jabran, K.; Farooq, M. Optimizing row spacing in wheat cultivars differing in tillering and stature for higher productivity. Arch. Agron. Soil Sci. 2013, 59, 1457-1470. [CrossRef]

29. Novacek, M.J.; Mason, S.C.; Galusha, T.D.; Yaseen, M. Twin-rows minimally impact irrigated maize yield, morpholog y and lodging. Agron. J. 2013, 105, 26-8276. [CrossRef]

30. Fischer, R.A.; Ramos, O.H.M.; Monasterio, I.O.; Sayre, K.D. Yield response to plant density, row spacing and raised beds in low latitude spring wheat with ample soil resources: An update. Field Crops Res. 2019, 232, 95-105. [CrossRef]

31. Abichou, M.; de Solan, B.; Andrieu, B. Architectural response of wheat cultivars to row spacing reveals altered perception of plant density. Front. Plant Sci. 2019, 10, 999. [CrossRef] 
32. Liu, T.; Wang, Z.; Cai, T. Canopy Apparent Photosynthetic Characteristics and Yield of Two Spike-Type Wheat Cultivars in Response to Row Spacing under High Plant Density. PLoS ONE 2016, 11, e0148582. [CrossRef] [PubMed]

33. Bastos, L.M.; Carciochi, W.; Lollato, R.P.; Jaenisch, B.R.; Renzende, C.R.; Schwalbert, R.; Prasad, P.V.V.; Zhang, G.; Frotz, A.K.; Foster, C.; et al. Winter wheat yield response to plant density as a function of yield environment and tillering potential: A review and field studies. Front. Plant Sci. 2020, 11,1-17. [CrossRef]

34. Hussain, M.; Farooq, S.; Jabran, K.; Ijaz, M.; Sattar, A.; Hassan, W. Wheat Sown with Narrow Spacing Results in Higher Yield and Water Use Efficiency under Deficit Supplemental Irrigation at the Vegetative and Reproductive Stage. Agronomy 2016, 6, 22. [CrossRef]

35. Giraldo, P.; Benavente, E.; Manzano-Agugliaro, F.; Gimenez, E. Worldwide Research Trends on Wheat and Barley: A Bibliometric Comparative Analysis. Agronomy 2019, 9, 352. [CrossRef]

36. Reicosky, D.C. Conservation tillage is not conservation agriculture. J. Soil Water Conserv. 2015, 70, 103A-108A. [CrossRef]

37. Williams, A.; Davis, A.S.; Ewing, P.M.; Grandy, A.S.; Kane, D.A.; Koide, R.T.; Mortensen, D.A.; Smith, R.G.; Snapp, S.S.; Spokas, K.A.; et al. A comparison of soil hydrothermal properties in zonal and uniform tillage systems across the US Corn Belt. Geoderma 2016, 273, 12-19. [CrossRef]

38. Cociu, A. Tillage system effects on input efficiency of winter wheat, maize and soybean in rotation. Rom. Agric. Res. 2010, $27,81-89$.

39. Šarauskis, E.; Vaitauskienè, K.; Romaneckas, K.; Jasinskas, A.; Butkus, V.; Kriaučiūnienè, Z. Fuel consumption and $\mathrm{CO}_{2}$ emission analysis in different strip tillage scenarios. Energy 2017, 118, 957-968. [CrossRef]

40. WRB. World Reference Base for Soil Resources 2014. In International Soil Classification System for Naming Soils and Creating Legends for Soil Maps; IUSS Working Group WRB, World Soil Resources Reports No. 106; FAO: Rome, Italy, 2014.

41. Peel, M.C.; Finlayson, B.L.; McMahon, T.A. Updated world map of the Köppen-Geiger climate classification. Hydrol. Earth Syst. Sci. 2007, 11, 1633-1644. [CrossRef]

42. Kuśmierek-Tomaszewska, R.; Dudek, S.; Żarski, J.; Januszewska-Klapa, K. Temporal variability of drought in field crops in the region of Kujawsko-Pomorskie, Poland. Res. Rural Dev. 2018, 2, 62-68.

43. Statistica. Data Analysis Software System, Version 12; TIBCO Software INC: Palo Alto, CA, USA, 2017; Available online: http: / / statistica.io (accessed on 15 January 2019).

44. Hossain, M.I.; Haque, M.E.; Meisner, C.A.; Sufian, M.A.; Rahman, M.M. Strip tillage planting method for better wheat establishment. J. Sci. Technol. 2005, 3, 91-95.

45. Jaskulska, I.; Gałazka, A.; Jaskulski, D. Strip-till as a means of decreasing spatial variability of winter barley within a field scale. Acta Agric. Scand. B-SP 2019, 69, 516-527. [CrossRef]

46. Jaskulska, I.; Jaskulski, D.; Różniak, M.; Radziemska, M.; Gałęzewski, L. Zonal tillage as innovative element of the technology of growing winter wheat: A field experiment under low rainfall conditions. Agriculture 2020, 10, 105. [CrossRef]

47. He, J.; Shi, Y.; Zhao, J.; Yu, Z. Strip rotary tillage with a two-year subsoiling interval enhances root growth and yield in wheat. Sci. Rep. 2019, 9, 11678. [CrossRef]

48. Hoque, M.; Miah, M.S. Evaluation of different tillage methods to assess BARI inclined plate planter. Agric. Eng. Int. 2015, $17,128-137$.

49. Alvarez, R.; Steinbach, H.S. A review of the effects of tillage systems on some soil physical properties, water content, nitrate availability and crops yield in the Argentine Pampas. Soil Tillage Res. 2009, 104, 1-15. [CrossRef]

50. Hossain, M.I.; Gathala, M.K.; Tiwari, T.P.; Hossain, M.S. Strip tillage seeding technique: A better option for utilizing residual soil moisture in rainfed moisture stress environments of North-West Bangladesh. Int. J. Recent Dev. Eng. Technol. 2014, 2, $132-136$.

51. Hasan, M.; Mahmud, K.; Islam, M.N.; Sarkar, P.K.; Shariot-Ullah, M. Water productivity and yield performances of wheat under different irrigation and tillage treatments. Fundam. Appl. Agric. 2017, 2, 196-201.

52. Gałęzewski, L.; Jaskulska, I.; Wilczewski, E.; Wenda-Piesik, A. Response of Yellow Lupine to the Proximity of Other Plants and Unplanted Path in Strip Intercropping. Agriculture 2020, 10, 285. [CrossRef]

53. Celik, A.; Altikat, S.; Way, T.R. Strip tillage width effects on sunflower seed emergence and yield. Soil Tillage Res. 2013, 131, 20-27. [CrossRef]

54. Tabatabaeekoloor, R. Soil characteristics at the in-row and inter-row zones after strip-tillage. Afr. J. Agric. Res. 2011, 6, 6598-6603. [CrossRef]

55. Overstreet, L.F.; Hoyt, G.D. Effects of strip-tillage and production inputs on soil biology across a spatial gradient. Soil Sci. Soc. Am. J. 2008, 72, 1454-1463. [CrossRef]

56. Fernández, F.G.; White, C. No-till and strip-till corn production with broadcast and subsurface-band phosphorus and potassium. Agron. J. 2012, 104, 996-1005. [CrossRef]

57. Jaskulska, I.; Romaneckas, K.; Jaskulski, D.; Gałęzewski, L.; Breza-Boruta, B.; Dębska, B.; Lemanowicz, J. Soil Properties after Eight Years of the Use of Strip-Till One-Pass Technology. Agronomy 2020, 10, 1596. [CrossRef]

58. Celik, A.; Ozturk, I.; Way, T.R. Effects of various planters on emergence and seed distribution uniformity of sunflower. Appl. Eng. Agric. 2007, 23, 57-61. [CrossRef]

59. Song, X.; Yang, G.; Yang, C.; Wang, J.; Cui, B. Spatial variability analysis of within-field winter wheat nitrogen and grain quality using canopy fluorescence sensor measurements. Remote Sens. 2017, 9, 237. [CrossRef] 
60. Masino, A.; Rugeroni, P.; Borrás, L.; Rotundo, J.L. Spatial and temporal plant-to-plant variability effects on soybean yield. Eur. J. Agron. 2018, 98, 14-24. [CrossRef]

61. Jaskulska, I.; Gałęzewski, L.; Piekarczyk, M.; Jaskulski, D. Strip-till technology-A method for uniformity in the emergence and plant growth of winter rapeseed (Brassica napus L.) in different environmental conditions of Northern Poland. Ital. J. Agron. 2018, 13, 194-199. [CrossRef]

62. Goins, G.D.; Yorio, N.C.; Sanwo, M.M.; Brown, C.S. Photomorphogenesis, photosynthesis, and seed yield of wheat plants grown under red light-emitting diodes (LEDs) with and without supplemental blue lighting. J. Exp. Bot. 1997, 48, 1407-1413. [CrossRef]

63. Sparkes, D.L.; King, M. Disentangling the effects of PAR and R: FR on lodging-associated characters of wheat. Ann. Appl. Biol. 2008, 152, 1-9. [CrossRef]

64. Shah, A.N.; Tanveer, M.; ur Rehman, A.; Anjum, S.A.; Iqbal, J.; Ahmad, R. Lodging stress in cereal-Effects and management: An overview. Environ. Sci. Pollut. Res. 2017, 24, 5222-5237. [CrossRef] [PubMed]

65. Khobra, L.; Sereen, S.; Meena, B.K.; Kumar, A.; Tivari, V.; Singh, G.P. Exploring the traits for lodging tolerance in wheat genotypes: A review. Physiol. Mol. Biol. Plants 2019, 25, 589-600. [CrossRef]

66. Zhang, L.; Hu, Z.; Fan, J.; Zhou, D.; Tang, F. A meta-analysis of the canopy light extinction coefficient in terrestrial ecosystems. Front. Earth Sci. 2014, 8, 599-609. [CrossRef]

67. Burgess, A.J.; Retkute, R.; Herman, T.; Murchie, E.H. Exploring relationships between canopy architecture, light distribution, and photosynthesis in contrasting rice genotypes using 3D canopy reconstruction. Front. Plant Sci. 2017, 8, 734. [CrossRef]

68. Khabiri, E.; Jafari, M. The effect of different light levels on the growth of wheat gascogne. Int. Res. J. Appl. Basic Sci. 2012, 3, 2358-2363.

69. Pradhan, S.; Sehgal, V.K.; Bandyopadhyay, K.K.; Panigrahi, P.; Parihar, C.M.; Jat, S.L. Radiation interception, extinction coefficient and use efficiency of wheat crop at various irrigation and nitrogen levels in a semi-arid location. Ind. J. Plant. Physiol. 2018, 23, 416-425. [CrossRef]

70. Elli, E.F.; Caron, B.O.; Medeiros, S.L.P.; Eloy, E.; Monteiro, G.C.; Schmidt, D. Effects of growth reducer and nitrogen fertilization on morphological variables, SPAD index, interception of radiation and productivity of wheat. Rev. Ceres. 2015, 62, 577-582. [CrossRef] 